NBER WORKING PAPER SERIES

\title{
CONVEYING QUALITY AND VALUE IN EMERGING INDUSTRIES: STAR SCIENTISTS AND THE ROLE OF LEARNING IN BIOTECHNOLOGY
}

\author{
Matthew J. Higgins \\ Paula E. Stephan \\ Jerry G. Thursby \\ Working Paper 14602 \\ http://www.nber.org/papers/w14602
}

\author{
NATIONAL BUREAU OF ECONOMIC RESEARCH \\ 1050 Massachusetts Avenue \\ Cambridge, MA 02138 \\ December 2008
}

\begin{abstract}
We have benefited from discussions with colleagues at Georgia State University, University of Nebraska, Emory University, Georgia Institute of Technology, Purdue University, Katholieke Universiteit Leuven, the NBER Working Group on Higher Education and the Roundtable for Engineering Entrepreneurship. David Audretsch, Jim Adams, Bill Amis, Chris Bollinger, Irwin Feller, Shiferu Gurmu, Joshua Lerner, Sharon Levin, Frank Rothaermel, Judith Ruud, Marie Thursby, Leslie Harris-Vincent and Mary Beth Walker provided useful comments on this research. We thank Mark Edwards at Recombinant Capital for access to their data and Meghan Crimmins, Daniel Hall, Richard Hawkins and Anne Gilbert for assistance in coding. Stephan acknowledges financial support from the Science and Engineering Workforce Project, NBER. Higgins acknowledges financial support from the National Science Foundation IGERT Fellowship (Grant \#0221600) and the Imlay Professorship. The views expressed herein are those of the author(s) and do not necessarily reflect the views of the National Bureau of Economic Research.
\end{abstract}

NBER working papers are circulated for discussion and comment purposes. They have not been peerreviewed or been subject to the review by the NBER Board of Directors that accompanies official NBER publications.

(C) 2008 by Matthew J. Higgins, Paula E. Stephan, and Jerry G. Thursby. All rights reserved. Short sections of text, not to exceed two paragraphs, may be quoted without explicit permission provided that full credit, including $\odot$ notice, is given to the source. 
Conveying Quality and Value in Emerging Industries: Star Scientists and the Role of Learning in Biotechnology

Matthew J. Higgins, Paula E. Stephan, and Jerry G. Thursby

NBER Working Paper No. 14602

December 2008

JEL No. D80,G10,J33

\begin{abstract}
Managers of private entrepreneurial firms face obstacles in raising capital both in placing a value on a firm and conveying value to investors. These problems are exacerbated when the firm is small, has limited assets (except for human capital) and has yet to have a lead product. In such cases metrics are necessary to convey the value of the firm to investors. Here we explore the importance within the biotechnology industry of the non-financial metrics firms used to convey value during two important initial public offerings (IPO) windows (1989 to 1992 and 1996 to 2000). We also examine whether there was a change over time in the importance of various metrics in determining the value of a biotechnology firm. We find that firms with an affiliated Nobel laureate succeeded in raising the value of their firms by more than $\$ 30$ million compared to firms without a Nobel laureate during the first period, suggesting that a Nobel laureate served as a powerful signal of firm value. Our results also suggest that the biotechnology regime changed and the Nobel Prize lost its luster as a signal of value in the second period. The importance of several other non-financial metrics changed as well. We conclude that these non-financial metrics of value change in relative importance to potential investors and financial markets as learning occurs and as an industry matures.
\end{abstract}

Matthew J. Higgins

Georgia Institute of Technology

800 West Peachtree Street

Atlanta, GA 30308

Matt.Higgins@mgt.gatech.edu

Paula E. Stephan

Department of Economics

Andrew Young School of Policy Studies

Georgia State University

Box 3992

Atlanta, GA 30302-3992

and NBER

pstephan@gsu.edu
Jerry G. Thursby

Georgia Institute of Technology

jerry.thursby@mgt.gatech.edu 


\subsection{Introduction}

An important obstacle that managers of private entrepreneurial firms face in raising capital is placing a valuation on their firm. An additional obstacle is conveying that value to investors. Often these firms are small, have limited assets and have a lead product yet to be marketed. These issues are compounded in knowledge intensive industries where much of a firm's assets are tied up in human capital and the underlying technologies are often radical and untested. Moreover, cash flows (and the prospect of cash flows) are often non-existent. These problems are exacerbated in "new" industries where there is little in the way of past performance to guide investors regarding the value of firms. In these cases valuation is much more an art than a science. As a result, metrics are necessary to convey the quality (value) of the firm to investors. The validity and usefulness of these metrics may change over time as learning takes place regarding the appropriateness of various metrics. In this paper we explore the importance within the biotechnology industry of the metrics firms used to convey value during two important initial public offering (IPO) windows.

The first window we explore occurred between 1989 and 1992; the second was between 1996 and 2000. During this time interval the industry can be considered relatively new, having only started to gain traction in the late 1970s to mid-1980s. Indeed, based on the number and volume of deals the 1990s arguably can be considered the main entry point of publicly traded biotechnology firms.

Our paper is grounded in two observations gleaned from an examination of the IPO prospectuses of these firms. First, the prospectuses frequently highlight the research accomplishments of university scientists associated with the firm, some of whom were Nobel laureates. Second, there is a clear difference between the "maturity" of the firms in the 1989 to 1992 window versus the 1996 to2000 window. The second-window firms typically were older, had more patents granted, and more products in phase trials, etc.

Here we ask two main questions. The first relates to non-financial metrics. It is clear that such things as patents awarded and products in phase trials are important for investor valuations of biotechnology firms. It is also clear from their prominence in the IPO prospectuses that an associated Nobel Prize winner is considered by the firm and its investment bankers to be important in firm valuation. The first question inquires into the relative and absolute importance of these metrics. The second question asks whether there was a change over time in the importance of various metrics in determining the value of a biotechnology firm. This question follows from the observation that there was a noticeable change in the magnitude of the metrics between the two periods. This suggests the possibility that learning had taken place on the part of the investment banking community and of investors regarding the appropriate level of importance to attach to various metrics. Given the infancy of this industry during the 1990s such an outcome would not be surprising.

To answer our questions we develop an econometric model of the relationship between various metrics of firm value and the observed value of the firm. Firm value is measured in two ways. First, we measure value based on the proceeds the firm received from the public offering adjusted by the percent of the firm 
sold in the offering. This is a valid measure in the sense that proceeds represent the amount that the investment bank warrants that the firm will receive from the offering and this value is set prior to the offering price and/or price range. As such, the firm's proceeds can be regarded as an indication of the investment bank's measure of value of the firm, although clearly it is not a perfect measure. The second measure is the value of the firm at the end of the first day of trading. This can be regarded as a measure of investor valuation of the firm. $^{2}$ We find that the two measures of value give reassuringly similar results in our econometric analysis although the second measure appears to be more "noisy" in that t-statistics of estimated coefficients are generally smaller as is the $\mathrm{R}^{2}$.

From our perspective the biotechnology industry provides a fertile setting for a study of firm valuation in a knowledge intensive industry and how valuation can evolve over time. First, as noted above, the industry is relatively new. As a result entrepreneurs, investors and the market have had to develop nonfinancial metrics by which to evaluate firms (and the industry). Second, having these two distinct IPO windows allows us to analyze what non-financial metrics firms used to convey value in each period and how these metrics were perceived by the firm's investment bankers and investors. What makes these two public equity financing windows particularly interesting is that the early window (1989 to 1992), in many respects, represented a new biotechnology regime in that 1) prior offerings had rarely involved firms with so little in the way of a market track record, and 2) biotechnology was still a relatively new field with major scientific advances having only recently taken place in the late 1970's. By way of contrast, in the later period (1996 to2000) the biotechnology regime was more established in terms of intellectual property and, if not sales, at least alliances and products in clinical testing. Moreover, the industry had developed into one that was facilitating the move of research out of universities and eventually to the pharmaceutical industry (Stuart et al., 2007). As a result, it became clearer what the value proposition of the new industry was to the established pharmaceutical industry, university partners and the market.

If it is the case that this "new" industry matured over time, then we would expect to find changes in the importance of the metrics between the first and second periods. Certainly, as the first wave of firms aged during the 1990s more information became available to potential investors, the entrepreneurs themselves and the broader market. As such, we expect some of these metrics to have increased or diminished in importance. Operationally, a different regime should be reflected in different regression coefficients in a model of firm value.

We find that the most striking difference between these two periods is in the marked decrease in value attached to the association of a university-affiliated Nobel laureate ("star scientist") with the firm. In the

\footnotetext{
${ }^{2}$ The difference in the two measures of value relates to the important issue of underpricing (the difference between offering price and first day closing price). While this is an important phenomenon our interests lie in studying the relationship between a set of non-financial metrics and perceived value of the firm, not the well-studied phenomenon of underpricing. Underpricing was first documented by Stoll and Curley (1970), Logue (1973), Reilly (1973) and Ibbotson (1975) . The interested reader can consult Bialkin and Grant (1985), Ellis et al (2000), Foerster (2000), Killian et al (2001) and Ritter and Welch (2002) for discussions on underpricing and the process of going public in general.
} 
first window 8 of the 44 firms have 9 affiliated Nobel laureates, and, all else equal, the affiliation of a Nobel in this window adds about $\$ 30$ million to the value of the firm. A different picture emerges for the later public offering window. The 1996 to 2000 data cover 46 firms with 7 of them having a total of 10 affiliated Nobel laureates. In this latter period the presence of a Nobel laureate does not have a statistically significant effect on the amount of money raised.

Interestingly, and consistent with the regime change hypothesis discussed above, there is also an apparent change between the two windows in the importance of other non-financial metrics used to convey value. For example, there is less importance attached to alliances with other firms. This finding of a regime change is important since our research is one of the first to demonstrate the dynamic nature of signals across equity financing windows.

The plan of this paper is as follows. Section 2.0 examines the role and impact university-affiliated star scientists have on the value of biotechnology firms. Accessing the public equity markets for biotechnology firms is discussed in Section 3.0. Section 4.0 discusses the data and the sample. Section 5.0 presents regression results. We conclude in section 6.0. Included in this last section is information on the compensation packages of the Nobel laureates as well as a discussion of learning that may have occurred.

\subsection{The role of university-affiliated star scientists in biotechnology firms}

Unlike the extant literature that defines a star based on publication or citation counts (see for example, Rothaermel and Hess, 2007 or Zucker et al., 1998), here we define a star as a university-affiliated scientist who is also the recipient of a Nobel Prize. ${ }^{3}$ We choose this criterion because the Nobel Prize is the ultimate scientific accomplishment and there is little ambiguity as to its meaning with respect to the importance of an individual's work. While our definition of "star" might be considered strict, the meaning of the prize provides an unambiguous metric by which to explore our research questions. It is a readily available and highly visible sign to the investment community.

Stars - and their university colleagues - make several contributions to knowledge-intensive firms. First, because biotechnology firms are research intensive operations many of their employees are scientists and companies often obtain knowledge through relationships with university-affiliated star scientists. This form of knowledge transfer is particularly important in a field such as biotechnology where knowledge is often of a tacit nature and thus requires face-to-face interaction to effectively transfer knowledge; it is well

\footnotetext{
${ }^{3}$ In our econometric analysis we also consider more traditional measures of star scientists by looking at citation counts to publications of all university-affiliated scientists. We are thus able to parse out the effect between how "star" scientists are defined in the extant empirical literature and how we define it here. There are cases where there are other university-affiliated scientists in a firm that have higher citation counts than the Nobel reciepient, but this does not modify the effect of the presence of a Nobel Prize winner.
} 
established that the presence of a star scientist enhances firm performance in biotechnology (Zucker and Darby, 1997; Zucker, et. al, 2002.) ${ }^{4}$

In many instances university-affiliated star scientists play other roles than that of knowledge transfer, serving as reviewers or as links in networks between the firm and universities or the firm and other firms (Audretsch and Stephan, 1996; Powell, 1996). Furthermore, a scientific advisory board (SAB) composed of productive university-affiliated scientists can also play a crucial role in recruiting younger scientists to work with the firm. For example, George B. Rathmann, former Chairman, President and CEO of Amgen, attributed much of the company's success to a SAB of "great credibility" whose "members were willing to share the task of interviewing the early candidates for scientific positions." He went on to say that the young scientists they recruited would not have come to Amgen "without the knowledge that an outstanding scientific advisory board took Amgen seriously" (Burrill, 1988).

The association of high quality university-affiliated scientists can also lend legitimacy to the firm and its quest for resources and is especially important in the absence of tangible assets (Deeds et al., 2004). Indeed, in the early stages of firm development, scientists arguably are a firm's most important asset. This asset is particularly important because biotechnology firms have historically been prematurely born - having limited intellectual property, no products and hence no internal mechanism for funding research and development $(R \& D)$. One way the market can assess the prospects of such firms is by scrutinizing the abilities of the firm's scientists, including those with links to universities. For example, when asked what made DNAX worth $\$ 29$ million at the time it was acquired by Schering-Plough, a spokesman for the company said, “...the company's assets are far and away the working scientists and the scientific advisory board..." (Kenney, 1986). ${ }^{5}$ Such scrutiny may have proved especially effective during the rash of premature births that occurred during the early 1990s in biotechnology.

For these reasons, and because of the asymmetric information between biotechnology firms, venture capitalists, investment banks and the financial markets (discussed more fully in the next section), having a university-affiliated scientist who is a recipient of the Nobel Prize can serve as a very clear metric of quality that might otherwise be missed in a citation count or other measures of quality. Recipients, given the vetting process involved in the selection, can be viewed as the "ultimate stars" in their respective fields. As a result, we argue that investors will view this association with "quality" as a proxy for the underlying research being conducted by the firm. It is not so much that the laureates are doing the firm's research; but their presence assures investors and the market that the firm's research has been evaluated by the best and that the firm can

\footnotetext{
${ }^{4}$ In a different but related vein, Sine et al. (2003) find that the academic prestige of a university can positively influence the prospect of licensing a university technology. Elfenbein (2007) finds a similar result except that his focus is on the prestige of the university inventor.

${ }^{5}$ Scientists are also important assets for mature companies. Robert Swanson, CEO of Genentech, is quoted as saying "Our most important assets walk out in tennis shoes at 5 o'clock." He continues by talking about how these assets tend to walk back in at 10 in the evening to check an experiment, and how full parking lots are at Genentech on the weekend (Burrill 1988, p. 44).
} 
attract the best in terms of talent. Consistent with this hypothesis, we find that university-affiliated star scientists are highly touted in biotechnology prospectuses. Often these prospectuses read like proposals to the National Institutes of Health, both in terms of the projects that they describe and in terms of the accomplishments of the university-affiliated scientists involved with the firms. Table 1 provides examples of the kinds of entries found in these prospectuses.

\subsection{Accessing capital through the public equity process}

For many years the conventional wisdom in biotechnology was that you could only take a firm public if the company had a product in late-stage clinical testing. For example, when Genentech went public in 1980 the company already had an agreement with Eli Lilly to manufacture and market the firm's human insulin product. However, even having a product in clinical trials does not always guarantee a successful offering. The public equity market is notorious for going through both "hot" and "cold" periods. ${ }^{6}$ For biotechnology the equity financing window originally opened in 1980 with the Genentech offering. In 1983 Amgen, Applied Biosystems, Biogen and Chiron all went public. In 1984 and 1985 the window was virtually closed, only to open somewhat in 1986 and early 1987. The stock market crash of 1987 all but closed the window for a significant period of time. The window began to open again in 1989 and 1990.

In February 1991, Amgen received FDA approval for the first of a new class of genetically-engineered drugs designed to boost the immune system's ability to fight infectious disease. This event, along with the success of the Gulf War, ushered in an opening of the public financing window in biotechnology the magnitude of which had never before been witnessed in the U.S. Within the next twenty-four months, over 70 biotechnology-related firms went public, raising in excess of $\$ 2.3$ billion. ${ }^{7}$ Perhaps more extraordinary is that many of the firms that went public during this period had no products in late-stage clinical testing (Phase III). Sensing an open window during this time, firms rushed into going public. The philosophy was summarized aptly by Joshua Boger, the founder of Vertex, who, speaking retrospectively, said, "...the time to go to Wall Street was when Wall Street was ready" (Werth, 1994). This phenomenon is common to the public equity markets in general and not limited to just the biotechnology industry (Loughran and Ritter, 1995).

The central question and concern for an issuing firm in a public equity offering is the amount of money that can be raised which then directly translates into a measure of firm value. With an established business in a less cutting-edge industry, this is somewhat straightforward, as firm valuations are easier to generate. On the other hand, for biotechnology firms with few or limited products in any stage of clinical

\footnotetext{
${ }^{6}$ See, for example, Lerner et al. (2003) and Higgins (2007a) for discussions of the difficulty in raising money in cold periods.

7 Some of the firms included in these counts are only loosely related to biotechnology but took advantage of the window to market themselves as a biotech firm. In our econometric analysis we use a strict filter to identify biotechnology firms solely focused on drug and diagnostic development.
} 
testing and the lack of revenues for the foreseeable future, this process is more complex and difficult (Higgins, 2007b). One common valuation method, favored by venture capitalists, attempts to place values on these types of companies using comparables from similar firms (Metrick, 2006; Higgins, 2007b). Unfortunately, accounting data and relevant comparables in many of these cases are simply too unreliable a measure (Ritter and Welch, 2002). Furthermore, finding comparable companies for biotechnology firms is often problematic - sometimes they simply do not exist given the cutting edge nature of the underlying technology. In addition, it is difficult to gauge the market's appetite for a firm whose first substantial earning prospects are years away, whose flagship product may fail to get regulatory approval, or whose patents may be contested in court.

As a result of these challenges, information asymmetries clearly exist between biotechnology firms that want to raise money and the investment banking community and financial markets. These information asymmetries impact biotechnology firm valuations and the amount of money the firm can raise. In general, the larger the information asymmetry present, the higher is the risk with which the offering is viewed, and this negatively impacts the amount of money that can be raised (Ritter and Welch, 2002). In an effort to alleviate some of this information asymmetry, firms attempt to develop non-financial metrics to convey their quality. Examples include: prior alliances with pharmaceutical firms (Nicholson et al., 2005), the percent of the firm sold (Brau and Fawcett, 2006), depth of their research pipeline; quality of their patent portfolio (Hsu and Ziedonis, 2007), venture capital backing (Meggison and Weiss, 1991), and the prestige of the underwriter (Meggison and Weiss, 1991; Higgins and Gulati, 2003).

Our earlier discussion provides an additional non-financial metric by which biotechnology firms can convey their quality, thereby decreasing the amount of asymmetric information in their offering and as a result increasing the amount of money raised. To wit, the association of highly regarded university-affiliated scientists, namely Nobel laureates, conveys (1) that the firm has able minds working to bring a product to market--if not the minds of the stars themselves, then that of the talent that the stars recruit to work in the firm and (2) that the scientific community itself thinks highly of the firm.

To summarize, our primary focus in this study is the value of a firm at the time of the IPO and what drives a determination of the value of a firm (by either the firm's investment bankers or the market). More specifically we focus on the non-financial metrics firms utilize in an attempt to differentiate themselves to investors and, more importantly, whether their importance changes over time. We see this latter to be of especial importance in the context of a developing industry. Of particular interest is the reputation of the university-affiliated scientist while controlling for other metrics previously shown to be useful. Although we focus on the Nobel Prize ("star scientist"), we also consider reputation by citation counts to articles written by all university-affiliated scientists.

\subsection{Econometric Model}


Data for our sample of firms are drawn primarily from the final IPO prospectuses issued when the firms went public. In establishing our sample we use a narrow definition of biotechnology in that we include firms in the following SIC codes: 2834 (pharmaceutical preparations), 2835 (diagnostic substances), 2836 (biological products), 2869 (organic chemicals), and 8731 (physical research). Firms in these SIC codes were limited to those conducting human drug or diagnostic research. From this we identify 90 firms. ${ }^{8}$ In using a narrow definition of biotechnology we avoid some issues of unidentified heterogeneity across biotechnology firm "types." Additional deal information was gathered from Securities Data Corporation (SDC). Financial and equity information was supplemented from Compustat, Research Insight and CRSP. Alliance data was gathered from Recombinant Capital, a leading biotechnology consulting firm. Additional researchpipeline data was gathered from Pharmaprojects.

\subsection{Firm Value}

The dependent variable of interest is the value of the firm at the time of the IPO. Two measures of value are considered. The first measure is derived from the proceeds the firm receives from the public offering. This amount is determined in consultation with the investment bank. The value is set prior to the offering price and/or price range, and in most cases is decided well before an offering price is chosen. The firm's proceeds can be regarded as an indication of the investment bank's measure of value of the firm; although clearly it is not a perfect measure. From the proceeds we calculate the value of the firm by dividing by the fraction of the firm's total shares sold on the first day of trading. We refer to this measure as $V A L$ -

UE_PROCEEDS. The second measure is the value of the firm at the close of the first day of trading. This is a measure of investor valuation of the firm and is calculated as the price at the close of the first day times the number of shares sold and divided by the fraction of the total shares sold on the first day of trading. We refer to this measure as VALUE_CLOSING. Both measures are in current dollars.

The two measures are generally different. The average of VALUE_CLOSING is just over $20 \%$ larger than the average of VALUE_PROCEEDS. The difference in the measures involves the issue of underpricing, which is the difference between offering price and first day closing price. Though there is substantial interest in and a corresponding literature dealing with underpricing we do not consider it in this paper since our interest is solely in the value of biotechnology firms at the time of an IPO and how that value relates to a set of metrics.

We relate the value of a biotechnology firm measured either by VALUE_PROCEEDS or VAL$U E \_C L O S I N G$ to a set of regressors we believe to be related to the value of a firm.

\subsection{Nobel Laureates}

We define an indicator variable for whether there is a Nobel Prize winner associated with the firm either as a founder or member of the scientific advisory board $(N O B E L=1$ if there is an affiliated Nobel Prize

\footnotetext{
${ }^{8}$ This is in contrast to definitions used by Gao et al. ((2004) who identify 343 biotechnology IPOs between 1991 an 2000 and Lerner (1994) who identified 136 biotechnology IPOs between 1991 and 2000.
} 
winner, 0 otherwise). The relation between NOBEL and firm value is one of our key questions and stems from the prominence given to star university scientists in IPO prospectuses.

In the early window, nine of the university-affiliated scientists with eight of the firms had received a Nobel Prize. Likewise, in the later window, ten of the university-affiliated scientists with seven firms had received a Nobel Prize. As argued earlier, star scientists may give credibility to the underlying research being conducted by a biotechnology firm and/or their presence may make it easier for the firm to attract other top scientists. NOBEL is expected to be positively related to valuation.

There is substantial variation in the elapsed time between the date the Noble Prize was awarded and the date of the public equity offering. For the early window, 7 laureates had been awarded their prize within 7 years of the equity offering; one had received the prize 16 years prior. The average number of elapsed years was 5.7. In the later window, only 2 Nobel prizes had been awarded within the prior 7 years. Four prizes were awarded more than 23 years before the equity offering and one was awarded 42 years prior to the equity offering, for an average elapsed number of years of 23.3. The mean years elaspsed are statistically significantly different between the two periods (p-value in a test of differences is 0.021 ). To capture any time depreciation in the value of a Nobel to the success of a firm we include the product of the indicator of the presence of a Nobel laureate and the number of years since receiving the award. Variable NOBEL_AGE modifies the effect of NOBEL; the effect of a Nobel laureate becomes the coefficient of NOBEL plus the coefficient of NOBEL_AGE times the number of elapsed years since receiving the award. We expect NOBEL_AGE to modify downward the expected positive effect of NOBEL on valuation.

\subsection{Research pipeline and intellectual property portfolio}

The future of the firms and their potential products is highly uncertain. Not only is there the technical uncertainty involved in development, but also the products must undergo clinical testing and FDA approval. We include the number of products the firm has in some stage of clinical testing (PHASE) as a measure of how far along products are in the development process and how close they are to being submitted for FDA approval. ${ }^{9}$ The more drugs or devices in clinical trials, the less uncertain is the future for the firm's product pipeline. PHASE is expected to be positively related to firm value. ${ }^{10}$ Over the entire sample 53 firms (21 firms in the early window and 32 in the later window) had at least one product in some stage of clinical testing. In the early period the number of products in clinical testing averaged 1.14. In the later period the mean had increased by almost two-thirds to 1.89 . The mean of the two counts is significantly different at a p-value of .047 .

\footnotetext{
${ }^{9}$ Clinical testing is broken down into three phases: Phase I involves safety testing; Phase II focuses on small-scale human efficacy trials; and, Phase III focuses on large-scale human efficacy trials.

${ }^{10}$ Four firms had products already approved by the FDA, but these products appear to have limited value. One firm announced in its prospectus that its approved product was being withdrawn from the market. The remaining three had small revenue flows.
} 
In addition to a firm's current research pipeline we also include information about the underlying patent portfolio of each firm. First, we consider the number of patents to which the firm has exclusive rights at the date of their public equity offering (PATENTS). ${ }^{11}$ Thirty-five firms ( 6 in the early window and 29 in the later window) have patents by the date of their public equity offering. For firms with patents the mean number of patents in the early period is 3.6 and in the later period it is 10.5 . The average number of patents per firm is 0.5 in the first period and 6.7 in the second (p-value for the difference is 0.003 ). Second, as a measure of how important (fundamental) these underlying patents are we also include the number of U.S. citations received within three years after the date of the public equity offering (PATENT_CITES). In the early window, the average number of citations per patent was 1.68. By the later window the average had risen substantially to 20.36. Citations per firm, however, rises from 1.1 to only 2.8 (not significantly different from zero). We expect PATENTS and PATENT_CITES to be positively related to firm value.

\subsection{Strategic alliances}

An extensive literature focuses on strategic alliances between biotechnology and pharmaceutical firms. However, the effect these alliances have on the proceeds of public equity offering is uncertain. On the one hand, Nicholson et al (2005) show that having an initial alliance with a pharmaceutical firm serves as a positive signal to the market. ${ }^{12}$ Such an alliance should be viewed as relationships that will be beneficial to both parties. As a result, a portfolio of many alliances can positively impact the amount of money a firm can raise. On the other hand, alliances can also be an encumbrance on future activities, revenues and/or intellectual property ownership. These issues can be exacerbated depending on how the underlying control rights are allocated (Higgins, 2007a; Adegbesan and Higgins, 2007; Hansen and Higgins, 2007). Essentially, it is possible that a few alliances can provide a positive signal about the firm whereas many alliances might be a negative signal due to potential future encumbrances.

Over the entire sample 70 firms had at least one alliance. Only 28 of the 44 firms in the early window had alliances while 42 of the 46 firms in the later window had alliances. The average number for the 44 firms in the early period was 3.6 while the average in the second period was larger at 8 alliances; the difference is statistically highly significant. Maximum numbers of alliances, however, are similar: 32 for one firm in the early window and 35 for a firm in the later window. To capture the potential nonlinear effect of the number of alliances we include both the number of alliances (ALLIANCES) and the square of the number of alliances $\left(A L L \_S Q\right)$. Our expectation is that $A L L I A N C E S$ will have a positive coefficient and $A L L \_S Q$ will have a negative coefficient.

\footnotetext{
${ }^{11}$ The patent variable was coded from the final IPO prospectuses and measures the number of patents to which the firm has exclusive rights. Thus, the measure captures not only patents issued directly to the firm, but patents acquired through arrangements with other firms. In several instances where the prospectuses did not report patent information, the patent variable was constructed by measuring the number of patents (as reported by the U.S. Patent Office) issued to the firm up to the date of the IPO.

${ }^{12}$ For the semiconductor industry Hsu and Ziedonis (2007) find that the impact of reputable alliance partners dimishes when patent stocks are taken into consideration.
} 


\subsection{Percent of the firm being sold}

The percentage of the firm to be sold during a public equity offering represents an important decision for the owners given the loss of control and future returns that occur as more of the company is sold. While it is doubtful that the market cares a great deal about the loss of control, it is likely that the market would view a sale of a large portion of the firm as a negative sign (Leland and Pyle, 1977; Brau and Fawcett, 2006). If the current owners seek to divest themselves of a large share of the company, then it may be that they have negative inside information. To capture this effect we include the log of the percent of the total shares of the firm that are sold (PERCENT_SOLD). Therefore, we expect PERCENT_SOLD to be negatively related to firm value. The percent of the company sold varies from 18 to 84 percent with a mean of 66 percent in the early window and 4.5 to 75 percent with a mean of 58 percent in the later window. The means are significantly different at a p-vale of .008.

\subsection{Reputation of investment bankers}

The effect of the investment bank's reputation on public equity offerings is well studied in the finance literature. Higher quality firms serve to reduce information asymmetries and mitigate the adverse selection problems faced by external investors (McLaughlin et al., 2000). Additionally, firms issuing equity can signal favorable private information by choosing higher quality investment banks (Booth and Smith, 1986; Titman and Trueman, 1986; Carter et al., 1998). Chemmanur and Fulghieri (1994) argue that investors use the past performance of an investment bank to determine credibility. Their findings suggest that higher reputation firms generate higher IPO proceeds. As a result, we follow Megginson and Weiss (1991) and construct a proxy for the reputation of the investment banking firm based upon relative market share. For each year of our sample we rank the top 25 investment banks based upon total IPO proceeds gathered from Securities Data Corporation (SDC). Relative market shares for the investment banks are then determined. ${ }^{13}$ The two means are not significantly different. Consistent with Chemmanur and Fulghieri (1994) we expect manager market share (MGR_SHARE) to be positively related to firm value.

\subsection{Additional firm controls}

The majority of our firms have limited product-based revenues. Most of the revenues they do have are from strategic alliances, grants or other types of research funding. As such, determining the size of the firm based on a measure of revenues or total assets would be inappropriate. We follow Graham and Higgins (2007) and use the number of employees (EMPLOYEES) to proxy firm size. The biotechnology industry is knowledge intensive and a firm's most important asset may very well be intangible in nature. As a result, all else being equal, large firms should be able to raise more money than smaller firms. The correlation between revenues and the number of employees is positive, but small (0.37). The number of employees ranges from 5 to 276 with a mean of 74 over the entire sample. Firms in the early window are smaller (58 employees on

13 In each year, the $25^{\text {th }}$ ranked underwriter had a relative market share of 0.1 percent. As a result, we assigned a relative market share of 0.1 percent to any underwriter that was in the sample that was not on this list of 25 . 
average) than the firms in the later window (88 employees on average). These means are statistically significantly different ( $\mathrm{p}$-value $=0.015)$.

In addition to the prestige of the underwriter we follow the literature (e.g., Meggison and Weiss, 1991; Brau and Fawcett, 2006) and control for venture capital backing for the firm. In the early period 40 of the 44 firms had venture backing while in the later period only 34 of 46 were venture backed. VENTURE is equal to one if the firm had venture capital backing. The fractions of venture backed firms are significantly different across the two periods ( $\mathrm{p}$-value $=0.034$ ).

Market conditions are one of the main factors that influence a firms' decision to go public (Lerner, 1994). We know that IPO markets go through 'hot' and 'cold' periods. In order to control for the market conditions for biotechnology IPOs we define BIO_RATIO as the ratio of biotechnology IPOs divided by the total number of IPOs in a given year.

Finally, for firms engaged in $R \& D$ activities it is common to use the ratio of $R \& D$ expenditure to revenue as a measure of $R \& D$ "intensity." However, each of these firms is $R \& D$ intensive and their revenue streams are generally small. In addition, and perhaps more importantly, the revenue streams are largely from license revenue and revenue stemming from alliances rather than revenue from product sales. For this reason we doubt that the value of current revenue is a valid predictor of the potential success of these firms. As a result, rather than use the ratio of $R \& D$ expenditure to revenue we use only the level of $R \& D$ expenditures. To smooth out the figures we use the sum of R\&D expenditures (measured in current dollars) for the three years prior to the public equity offering $\left(R \& D \_E X P E N D\right)$. Since all of these firms are R\&D intensive (indeed, they are not much more than a "bundle" of R\&D and intellectual property), what is likely to be the case is that this, along with the number of employees, will be a measure of firm size and therefore should have a positive effect on firm value.

\subsection{Summary Statistics}

Variables and definitions are presented in Table 2. Summary statistics for the early and later windows are found in Table 3, Panel A and Panel B, respectively. The reason for separating statistics according to the window is to emphasize the fact noted in the introduction that the firms in the second period are more mature than those in the early period in the sense that the levels of the variables are generally greater in the later window. With the exception of VENTURE, NOBEL and PERCENT_SOLD all later window levels are greater than early window levels. In the last column of Table 3 are the p-values from tests of differences in the average values. With only a few exceptions the means are statistically significantly different.

Also shown in the table are summary statistics for four regressors we consider in our robustness checks. These are the total of revenues received by the firm in the three years prior to the IPO (REVENUES), the total number of citations to publications of all the university affiliated scientists (TOTAL_CITES), the maximum number of citations received by the university affiliated scientists (MAX_CITES) and the age in 
months of the firm at the time of the IPO $(A G E)$. The mean level of each of these variables is statistically significantly larger in the second window.

Not shown in the table is the average elapsed time since a Nobel was awarded for the firms with Nobel laureates. The average elapsed time since the awarding of the Nobel Prize in the early window is 5.75 years which is statistically significantly smaller than the 23.29 years for the later window (p-value $=.021$ ).

Finally, we note that none of the firms had a marketable biotechnology product at the time they went public. Several had revenue from strategic alliances and other relationships, but all were operating in the red and sales-based revenue was generally small. For the three years prior to their offering, 21 of the earlywindow firms had revenue of less than $\$ 1.3$ million, while only 6 had revenue in excess of $\$ 13$ million (in current dollars). Average total revenue for these firms in the three years prior to their offering was $\$ 5$ million. In contrast, for the three years prior to their offering, only 11 of the later window firms had revenue of less than $\$ 1.3$ million, while 13 had revenue in excess of $\$ 13$ million (in current dollars). Average total revenue for these firms in the three years prior to their offering was approximately $\$ 10$ million. It is remarkable that despite having no marketable products and limited revenue, the average firm value (based on proceeds) was $\$ 65.5$ million in the early window and $\$ 152.1$ million in the later window.

\subsection{Early versus later window controls}

The substantial difference in the levels of most variables across the two windows suggests the possibility of a regime change brought about by learning between the early and late windows. Operationally we model regime change as a change in one or more of the coefficients in our models between the two windows. To test for the presence of a regime change we define the indicator variable LATE to be equal to one if the window is the late window 1996 to 2000 and zero otherwise. LATE is interacted with each of the above variables:

$\begin{array}{lll}L \_N O B E L & = & \text { LATE*NOBEL } \\ \text { L_NOBEL_AGE } & = & \text { LATE*NOBEL_AGE } \\ \text { L_PERCENT_SOLD } & = & \text { LATE*PERCENT_SOLD } \\ \text { L_ALLIANCES } & = & \text { LATE*ALLIANCES } \\ \text { L_ALL_SQ } & = & \text { LATE*ALL_SQ } \\ \text { L_EMPLOYEES } & = & \text { LATE*EMPLOYEES } \\ \text { L_MGR_SHARE } & = & \text { LATE*MGR_SHARE } \\ \text { L_PHASE } & = & \text { LATE*PHASE } \\ \text { L_PATENTS } & = & \text { LATE*PATENTS } \\ \text { L_PATENT_CITES } & = & \text { LATE*PATENT_CITES } \\ \text { L_R\&D_EXPEND } & = & \text { LATE*R\&D_EXPEND } \\ \text { L_VENTURE } & = & \text { LATE*VENTURE } \\ \text { L_BIO_RATIO } & = & \text { LATE*BIO_RATIO }\end{array}$

\subsection{Econometric Results}

The method of estimation is least squares with robust standard errors. Fixed and random effects were considered using year effects. A Hausman test revealed no significant difference in the estimators. However, 
the random effects model revealed a zero variance for the cohort effects; thus ordinary least squares is appropriate. All data are converted to logarithms with the exception of the indicator variables $L A T E$ and $V E N$ TURE and the count variables PATENTS, PATENT_CITES and ALLIANCES, as well as ALL_SQ and BIO_RATIO. Results for both measures of the dependent variable are in Panel A of Table 4.

With the exception of the coefficient on PATENTS (which is not significantly different from zero in either regression) all regressors for which we have priors regarding their signs satisfy our priors. We then dropped regressors that are interactions between $L A T E$ and some variable and which have t-statistics less than one in each of the regressions The dropped regressors are L_EMPLOYEES, L_PHASE, L_VENTURE and L_BIO_RATIO. In the resulting regression neither L_MGT_SHARE nor L_PATENTS have t-statistics larger than one in either regression, hence they are dropped. Results are in Panel B of Table 4. Results are very similar for the two measures of firm value; however VALUE_CLOSING exhibits slightly more noise in that fewer coefficients are statistically different from zero and the R-square is smaller. We will concentrate on the VALUE_PROCEEDS results.

\subsection{First window}

We begin with the first window VALUE_PROCEEDS results in Panel B (i.e., results when LATE = $0)$. With the exception of PATENTS_CITES and VENTURE all coefficients are significantly different from zero. With the exception of PATENT_CITES all coefficients have expected signs. As expected, having a few alliances increases firm value, but the returns from adding additional alliances is decreasing. Combining the results for ALLIANCES and $A L L \_S Q$ the implication is that after nine alliances the marginal effect of adding another alliance is significantly negative. The median of VALUE_PROCEEDS for first window firms is $\$ 55.1$ million. At the median adding the first alliance adds around $\$ 1.9$ million to firm value and the second around \$1.6 million.

The most striking result for the first window is the very large effect that having a Noble laureate $(N O B E L)$ associated with the firm has on firm value and the fact that the value decreases as the elapsed time between the award of the prize and the date of the IPO increased. The marginal effect of NOBEL is the coefficient of NOBEL (0.944) plus the coefficient of NOBEL_AGE (-0.048) times the age of the Nobel. Consider the set of firms that did not have a Nobel laureate associated with their firms. The median value of $V A L$ UE_PROCEEDS for firms' without an affiliated Nobel laureate is $\$ 44.7$ million. For the firms with Nobel laureates, the median time elapsed since the prize is 5.7 years. Based on these medians we can infer that the addition of a Nobel laureate to a non-Nobel firm would have added about $\$ 30$ million to the firm's day one proceeds.

The results for this first period are clear. Having a Nobel laureate associated with the firm conveys a strong positive signal to potential investors regarding the future prospects of a firm. Later we consider whether the Nobel laureates themselves shared substantially in the value they added to their firms. Our findings also suggest that some of the metrics that have been shown elsewhere to convey value are valid predic- 
tors of firm value. However, citations to patents (which has a negative coefficient but is not significantly different from zero) and venture backing (which is positive but not different from zero) are not valid metrics in the early window.

\subsection{Second window}

Second window coefficients are the sum of a first window coefficient and the coefficient of the corresponding interaction term. As hypothesized, there is evidence of a regime change from the first window to the second as evidenced by the statistically significant coefficients on many of the interaction terms. Specifically, there is a significant difference between the two periods in the coefficients of NOBEL, NOBEL_AGE, PERCENT_SOLD, ALL_SQ, R\&D_EXPEND and PATENTS_CITES. Consider first NOBEL and NO-

$B E L \_A G E$. The sum of the coefficients of NOBEL and $L \_N O B E L$ is not significantly different from zero (pvalue $=0.586$ ). The same is true for the sum of the coefficients of NOBEL_AGE and $L \_N O B E L \_A G E$ (pvalue $=0.592$ ). The results suggest that the presence of a Nobel laureate had a substantial impact on firm value in the first window, but there was no effect in the second. The same phenomenon holds both for $A L$ LIANCES and ALL_SQ. Namely, the sum of the coefficients of ALLIANCES and L_ALLIANCES and the sum of the coefficients of $A L L \_S Q$ and $L \_A L L \_S Q$ are each not significantly different from zero (p-values = 0.567 and 0.660 , respectively). The effect of alliances disappears in the second period. $R \& D \_E X P E N D$ is positive and significant in the first period but its effect also disappears in the second period (p-value for test of the sum of $R \& D \_E X P E N D$ and $R \& D \_E X P E N D$ being equal to zero is 0.908).

The test of the sum of PERCENT_SOLD and L_PERCENT_SOLD is significantly different from zero ( $\mathrm{p}$-value $=0.000$ ). The effect of the percent of the firm sold on day one is negative in the first window and continues to be negative in the second period but the magnitude of the coefficient falls by about half between the two windows. PATENT_CITES does not have a significant effect in the first period, but in the second period it is positive and significantly different from zero.

\subsection{Alternative models}

Above we questioned the validity of revenues as a predictor of firm value. Nonetheless, as a check we include the log of the total revenues received by the firm in the three years prior to the IPO (REVENUES) as well as revenues interacted with $L A T E\left(L_{-} R E V E N U E S\right)$. Since the data are in logs, this is less restrictive than entering the $\log$ of the ratio of $R \& D$ to revenues. ${ }^{14}$ For the sake of parsimony we only consider firm value as measured by VALUE_PROCEEDS. Results are in Panel A of Table 5. The coefficient of these new regressors are neither individually nor jointly significantly different from zero. The other coefficients are almost identical to what is presented in Table 4. In particular the implied value of a Nobel is $\$ 30$ million.

We included the age at the time of the IPO of the firm in months $(A G E)$ and $A G E$ interacted with $\operatorname{LATE}\left(L \_A G E\right)$. Results are in Panel B. The coefficients of $A G E$ and L_AGE are negative and jointly, but

\footnotetext{
${ }^{14}$ That is, we relax the restriction that the coefficients of the log of revenues and the log of R\&D expenditures are equal in absolute value.
} 
not individually, significant at the $10 \%$ level ( $\mathrm{p}$-value $=0.0763$ ). Again, the results for the other regressors are only slightly different from those for the base model. The implied value of a Nobel in period one is $\$ 30.5$ million.

Each Nobel laureate is associated with a university. This raises the possibility that the value of a Nobel is, at least in part, a reflection of a tie to a university. As a measure of the reputation of all universityaffiliated scientists working with the firm, we added as a regressor the log of the total number of citation (TOTAL_CITES) these university researchers had received to their prior research at the time of the offering. We also include its interaction with LATE (L_TOTAL_CITES). Results are in Panel C of Table 5. The coefficient of TOTAL_CITES is positive but insignificant and the result for $L_{-} T O T A L \_C I T E S$ is counterintuitive in that it is negative and significantly different from zero. The other coefficients are very similar to those of the base model. The implied value of a Nobel laureate falls slightly to $\$ 27$ million.

We added the log of the maximum number of citations (MAX_CITES) received by any of the university scientists (including the Nobel laureates) as well as its value interacted with $L A T E$ (L_MAX_CITES). This should provide an indication of whether the Nobel effect is simply a "star scientist" effect or whether there is some special cachet to the presence of a Nobel. The coefficient of L_MAX_CITES is negative and significant. The other results are very similar to those of the base model. The implied value of a Nobel is $\$ 27.8$ million.

We have argued that this industry was relatively new at the beginning of the first window and still somewhat new at the end of the second window. Some accounting for industry maturation over this period might be informative. We choose to measure maturation as the cumulative number of biotechnology IPOs (CUM_BIOTECH) that had taken place prior to a particular IPO event. For example, Biomatrix Inc. went public at the end of June 1991. By that time there had been 18 prior IPOs during the first window; thus CUM_BIOTECH takes the value 18 for this observation. ${ }^{15}$ It is our expectation that CUM_BIOTECH will have a positive coefficient since a larger value indicates a more mature industry at the time of the IPO and thus more information about the industry that is available to investors. We also add the interaction of LATE and CUM_BIOTECH (L_CUM_BIOTECH). Results are in Panel E. Neither CUM_BIOTECH nor L_CUM_BIOTECH are significantly different from zero. A test of their joint significance has a p-value of 0.789. The implied value of a Nobel is $\$ 30.8$ million.

\subsection{Discussion and Conclusion}

Managers of small, entrepreneurial firms are faced with the difficult task of trying to value their firms appropriately and raise money. Firms attempt to convey the value or quality of their firm through the use of various non-financial metrics. For example, alliances with reputable partners (Nicholson et al, 2005)

\footnotetext{
${ }^{15}$ We do not have the number of biotechnology IPOs prior to the first window, but this is not a problem since adding that to each CUM_BIOTECH observation will not change the results (except for the regression constant term).
} 
and high quality investment bankers (Chemmanur and Fulghieri, 1994) have been shown to positively impact different mechanisms of valuation. However, lacking in the extant literature is a discussion on how these non-financial metrics arise for new and emerging industries and more importantly how these metrics change over time. Our research fills this important gap. Our results suggest that a Nobel laureate served as a powerful signal of firm value during the early period when biotechnology regimes were less established, both in terms of an industrial track record as well as in terms of firm metrics such as the number of patents and products in clinical trials. To wit, Nobel firms succeeded in raising the value of their firms by more than $\$ 30$ million compared to those without a Nobel affiliate.

Our results also suggest that the biotechnology regime changed. Between the early and later period, the Nobel Prize lost its luster as a signal of value and the importance of several other metrics changed, as well. This finding is important given that most of the extant literature on signaling and public equity offerings focuses on the importance of firm signals over a period of time but does not address the dynamic, changing nature of signals. Our results show that over time, metrics of value change in relative importance to potential investors and the financial markets. These changes can have profound implications for firms trying to value themselves or raise money.

We believe that these results are consistent with learning. At least three communities were at risk to learn: Nobel laureates, firms, and the investment community. The take away for firms from the early period was that having a Nobel laureate mattered. And firms appear to have paid attention to this by continuing to recruit Nobels. What some firms appear not to have taken away was the importance of having a recent Nobel. In the later period some firms recruited Nobels who were considerably more distant from their prize than in the earlier period. Concurrently, the market appeared to learn that Nobels were not an indicator of value. We do not know whether this was because concrete signals became more readily available, such as the number of patents, or because the Nobel firms did not perform up to expectations in the intervening years. What we do know is that the Nobel Prize lost its luster for investors.

What about Nobel laureates? Did they learn? In order to answer this question we must first examine the extent to which affiliated Nobels in the early period benefited personally from their involvement. The IPO prospectuses offer some insight into this. We examined the available information on the compensation packages of the Nobel laureates in the early window, all of whom are members of the scientific advisory board of the firms. These packages include cash payments, shares of stock and stock options. The specifics of the individual compensation packages are not disclosed. However, in every IPO prospectus principal shareholders must be identified. The firm must report total holdings of stock, warrants and options for directors, for all directors and officers as a group and for any stockholder who is the beneficial owner of 5 percent or more of the firm. In no case is a Nobel laureate an officer or member of a Board of Directors of any of the firms in question. As such, the Nobel laureate would be identified in the IPO prospectus if the laureate were a beneficial owner of 5 percent or more of the firm. No Nobel laureate is identified as a beneficial owner. 
Since the laureate could own up to 5 percent of the firm and not be identified in the IPO prospectus, the 5 percent figure provides an upper limit on their compensation package. Panel A of Table 6 details these upper limits which run from $\$ 4.02$ million to $\$ 15.13$ million. Even in the unlikely event that the Nobel laureates had these maximum holdings of almost 5 percent of their company, the values are still well below the approximately \$34 million our regression results suggest these individuals add to the value of their respective firm. ${ }^{16}$ We conclude that Nobel laureates did not capture the rents that they generated during the early period. What about the later period? Did Nobels, seeing foregone rents from the first period, seek higher compensation in the second period? Panel B in Table 6 presents the maximum possible compensation packages (5 percent positions) of the Nobel laureates in the later window. These are, on average, \$2.24 million less than the maximum compensation packages in the early period. This suggests that the Nobels were slow to learn their value. It is also consistent with the possibility that firms, with alternative means of conveying value at their disposal, placed diminished importance on the presence of a Nobel laureate or recognized that "older" Nobels might be worth less.

Our research makes two important contributions to the literature. First, when traditional nonfinancial metrics are lacking or rare, the market invents new ones, such as the Nobel Prize, to convey quality and thus reduce information asymmetries. Second, regimes change: a meaningful non-financial metric in one period need not retain its meaning in a later period. We argue that this is not only because the measurable characteristics of equity events change over time; it is also because of learning that occurs in the intervening years. While managers can successfully use various non-financial metrics to communicate value to investors and markets, they need to approach this difficult task with the knowledge that signals that have worked in the past might not be valid in the future.

What we have not addressed here is whether the Nobel laureates in the first window actually conveyed relevant information regarding the value of the firm. Given the paucity of information in the first window in comparison to the second, perhaps the presence of Nobels did convey information appropriate to determining the value of a firm. This is a subject of ongoing research.

\footnotetext{
${ }^{16}$ Admittedly, our evidence would be stronger if we were able to observe actual compensation packages rather than upper bounds.
} 


\section{References}

Adegbesan, T., Higgins, M.J., 2006. The intra-alliance division of value created through collaboration. Unpublished working paper, Georgia Institute of Technology College of Management. .

Audretsch, D., Stephan, P., 1996. Company-scientist locational links: The case of biotechnology. American Economic Review, 86, 641-652.

Bialkin, K., Grant, W., (eds.) 1985. Securities Underwriting, a Practitioner's Guide. New York: Practicing Law Institute.

Booth, J., Smith, R., 1986. Capital raising, underwriting and the certification process. Journal of Financial Economics 15, 261-281.

Brau, J., Fawcett, S., 2006. Initial public offerings: An analysis of theory and practice. Journal of Finance, 399- 435.

Burrill, G. S., 1988. Biotech 89: Into the Marketplace. San Francisco, CA: The Arthur Young High Technology Group.

Carter, R., Dark, F., Singh, A., 1998. Underwriter reputation, initial returns and the long-run performance of IPO stocks. Journal of Finance 53(1), 285-311.

Chemmanur, T., Fulghieri, P., 1994. Investment bank reputation, information production, and financial intermediation. Journal of Finance 49(1), 57-79.

Deeds, D.L., Mang, P., Frandsen, M., 2004. The influence of firms' and industries' legitimacy on the flow of capital into high-technology ventures. Strategic Organization 2(1), 9-34.

Elfenbein, D., 2007. Publications, patents, and the market for university inventions. Journal of Economic Behavior \& Organization 63(4).

Ellis, K., Michaely, R., O'Hara, M., 2000. When the underwriter is the market marker: An examination of trading in the IPO aftermarket. Journal of Finance 55, 1039-1074.

Foerster, B., 2000. Securities Industry Association's Capital Markets Handbook. $2^{\text {nd }}$ Edition, Aspen Publishers.

Gao, R.J., Lev, B.I. and Zhou, N. The Valuation of Biotech IPOs, 2004, working paper.

Graham, S., Higgins, M.J., 2007. The impact of patenting on new product introductions in the pharmaceutical industry. Unpublished working paper, Georgia Institute of Technology College of Management. . Hansen, Z., Higgins, M.J., 2007. Technological uncertainty and the allocation of control rights in pharmaceutical alliances. Unpublished working paper, Washington University Olin School of Business.

Higgins, M.J., 2007a. The allocation of control rights in pharmaceutical alliances. Journal of Corporate Finance, 13, 58-75.

Higgins, M.J., 2007b. Introduction to finance and the valuation of early stage technologies. In G. Libecap (Ed.), Advances in the Study of Entrepreneurship, Innovation, and Economic Growth, Volume 18, Elsevier. 
Higgins, M., Gulati, R., 2003. Getting off to a good start: the effects of upper echelon affiliations on underwriter prestige. Organization Science 14(3), 244-263.

Hsu, D., Ziedonis, R., 2007. Patents as quality signals for entrepreneurial ventures. Unpublished working paper, Stephen M. Ross School of Business, University of Michigan.

Ibbotson, R., Jaffe, J., 1975. Hot issue' markets. Journal of Finance 30:1027-1042.

Kenney, M., 1986. Biotechnology: The University--Industrial Complex. New Haven: Yale University Press.

Killian, L., Smith, K., Smith, W., 2001. IPOs for Everyone. John Wiley \& Sons, New York.

Leland, H., Pyle, D., 1977. Information asymmetries, financial structure, and financial intermediation. Journal of Finance 32, 371-387.

Lerner, J., 1994. Venture capitalists and the decision to go public. Journal of Financial Economics 35, 293316.

Lerner, J., Shane, H., Tsai, A, 2003. Do equity financing cycles matter?: Evidence from biotechnology alliances. Journal of Financial Economics 67, 411-446.

Logue, D. E., 1973. On the pricing of unseasoned equity issues: 1965-1969. Journal of Financial Quantitative Analysis 8, 91-103.

Loughran, T., Ritter, J., 1995. The new issues puzzle. Journal of Finance 58, 723-752.

McLaughlin, R., Safieddine, A., Vasudevan, G., 2000. Investment banker reputation and the performance of seasoned equity issuers. Financial Management, 96-110.

Meggison, W., Weisss, K., 1991. Venture capitalist certification in initial public offerings. Journal of Finance 46(3), 879-901.

Metrick, A., 2006. Venture capital and the finance of innovation, New York, NY: John Wiley \& Sons.

Nicholson, S., Danzon, P., McCullough, J. 2005. Biotech-pharmaceutical alliances as a signal of asset and firm quality. Journal of Business 78, 1433-1464.

Powell, W.W., 1996. Interorganizational collaboration in the biotechnology industry. Journal of Institutional and Theoretical Economics 152(1), 197-216.

Reilly, F., 1973. Further evidence on short-run results for new issues investors. Journal of Financial Quantitative Analysis 8, 83-90.

Ritter, J.R., Welch, I., 2002. A review of IPO activity, pricing, and allocations. Journal of Financial Economics, 1795-1828.

Rothaermel, F.T., Hess, A., 2007. Building dynamic capabilities: Innovation driven by individual, firm, and network-level effects. Organization Science, forthcoming.

Sine, W., Shane, S., Di Gregorio, D., 2003. The halo effect and technology licensing: The influence of institutional prestige on the licensing of university inventions. Management Science 49(4), 478-496. 
Stoll, H., Curley, A., 1970. Small business and the new issues market for equities. Journal of Financial Quantitative Analysis 5, 309-322.

Stuart, T., Ozdemir, S., Ding, W., 2007. Vertical alliance networks: The case of university-biotechnologypharmaceutical alliance chains. Research Policy 36, 477-498.

Titman, S., Trueman, B., 1986. Information quality and the valuation of new issues. Journal of Accounting and Economics 8, 159-172.

Werth, B., 1994. The Billion-Dollar Molecule: One Company's Quest for the Perfect Drug. New York: Simon \& Schuster.

Zucker, L.G., Darby, M.R., 1997. Individual action and the demand for institutions: Star scientists and institutional transformation. American Behavioral Scientist 40, 502-153.

Zucker, L.G., Darby, M.R., Armstrong, J., 2002. Commercializing knowledge: University science, knowledge capture and firm performance in biotechnology. Management Science 48, 138-153.

Zucker, L.G., Darby, M.R., Brewer, M.B., 1998. Intellectual capital and the birth of U.S. biotechnology enterprises. American Economic Review 88, 290-306. 


\title{
Table 1: Examples of Biographical Entries of Nobel Prize Winners from IPO Prospectuses
}

\author{
R. Bruce Merrifield, Ph.D. (Alteon) \\ R. Bruce Merrifield, Ph.D., a Nobel Laureate, has been a member of the Scientific Advisory Board sine June 1991. He \\ is the John D. Rockefeller Professor of The Rockefeller University. He received his B.A. in Chemistry in 1943 and his \\ Ph.D. in biochemistry in 1949 at the University of California at Los Angeles and joined Rockefeller in 1949. Dr. Merri- \\ field's main scientific contribution, for which he was awarded the Nobel Prize in Chemistry in 1984, was the concept \\ and development of the technique of solid phase peptide synthesis, which is widely used in many areas of biology. He \\ was elected a member of the National Academy of Sciences in 1972. He has received several honorary degrees and \\ awards including the Lasker Award for Basic Medical Research in 1969 and the American Chemical Society Award for \\ Creative Work in Synthetic Organic Chemistry in 1972.
}

\section{Joshua Lederberg, Ph.D. (Antigenics)}

Joshua Lederberg, Ph.D., has been a member of the scientific advisory board since 1996 and is the board's Honorary Chairman. In 1958, at the age of 33, Dr. Lederberg received the Nobel Prize in Physiology of Medicine for his work in the field of bacterial genetics. Dr. Lederberg is currently the Sackler Foundation

Scholar and Professor- and President-Emeritus at The Rockefeller University, in New York City, where he is researching the interrelationships of DNA conformation and mutagenesis. Previously, Dr. Lederberg was a professor of genetics at Stanford University. A member of the National Academy of Sciences

and a charter member of its Institute of Medicine, Dr. Lederberg has served as chairman of the President's Cancer Panel and has chaired a comprehensive study of emergent infections sponsored by the Institute of Medicine, intended to counteract complacency about the threats from many infectious diseases. He has

also received the United States National Medal of Science. Dr. Lederberg has served on the board of the Procter \& Gamble Co., and continues as a part-time consultant to several financial and pharmaceutical research and development institutions. He received his Ph.D. from Yale University.

\section{Sir John Vane, D.Sc, F.R.S (CV Therapeutics)}

Sir John Vane, D.Sc., F.R.S., is the Director General of the William Harvey Research Institute at St. Bartholomew's Hospital Medical College in London. Prior to joining that institution, he spent 12 years as group research and development director at the Wellcome Foundation, Ltd. He was awarded the Nobel

Prize in 1982 for his work in prostaglandins and for discovering the mode of action of aspirin. Sir John was a research scientist for 18 years at the Royal College of Surgeons of England. He is highly regarded for his continuing research in the areas of cardiovascular disease and chronic inflammation. Sir John holds both a D.Phil. and D.Sc. and is a Fellow of the Royal Society, the Royal College of Physicians and the Royal College of Surgeons.

\section{E. Donnall Thomas, M.D. (Cell Therapeutics)}

E. Donnall Thomas, M.D., is the Chairman of cti's Clinical Advisory Board. He is the former Associate Director of Clinical Research and presently a Professor Emeritus at the FHCRC. Dr. Thomas was a founding Member of the FHCRC. His research has spanned a wide array of fields from radiation biology to developmental immunology, and from cancer causing genes to gene transfer therapies. For his pioneering work in BMT, Dr. Thomas was awarded the Nobel Prize for Medicine in 1990. His work demonstrated the feasibility and clinical effectiveness of marrow transplant therapy, and he has contributed to the training of a significant majority of the physicians now performing BMTs worldwide. Among the other honors awarded to Dr. Thomas in recognition of his medical research are the American Cancer Society Award for Distinguished Service in Basic Research and the Kettering Prize of the General Motors Cancer Research Foundation. He is a member of the U.S. National Academy of Sciences.

\section{Baruch S. Blumberg, M.D., PH.D. (Maygen)}

Baruch S. Blumberg, M.D., Ph.D., is a Distinguished Scientist at Fox Chase Cancer Center, Philadelphia, and University Professor of Medicine and Anthropology at the University of Pennsylvania. Dr. Blumberg's research has covered many areas including clinical research, epidemiology, virology, genetics and anthropology. Dr. Blumberg was awarded the Nobel Prize in 1976 for his work on infectious diseases and specifically for the discovery of the hepatitis B virus and has also been elected to the National Inventors Hall of Fame for similar work. Dr. Blumberg's research and insight into infectious diseases are valuable to Maxygen programs related to vaccines and hepatitis B in particular.

\section{Table 2: Variable Definitions}




\section{$\underline{\text { Variable }}$}

VALUE_PROCEEDS

VALUE_CLOSING

NOBEL

NOBEL_AGE

PERCENT_SOLD

ALLIANCES

$A L L_{-} S Q$

EMPLOYEES

$M G R \_S H A R E$

PHASE

PATENTS

PATENT_CITES

$R \& D \_E X P E N D$

LATE

VENTURE

CUM_BIOTECH

REVENUES

AGE

CITATIONS

MAX_CITES

\section{$\underline{\text { Definition }}$}

Firm valuation based on firm IPO proceeds raised, in millions

Firm valuation based on end of day one price, in millions

Dummy variable indicating if Nobel associated with firm

NOBEL interacted with number of years since Nobel and IPO

Percent of firm sold in IPO

Number of alliances

Square of ALLIANCES

Number of employees

Lead manager IPO market share

Number of products in clinical testing

Number of patents held by firm at IPO

Citations to patents held by IPO for three years following offering

$R \& D$ expenditures -3 year total

$=1$ if IPO is in late window, 1996 to 2000

$=1$ if the firm had received venture capital backing

Cumulative number of biotechnology IPOs

Revenues - 3 year total

Age of the firm in months at the time of the IPO

Total citations to all work of university-affiliated scientists

Maximum citations of university-affiliated scientists 
Table 3: Summary Statistics

Panel A: Early Period ( $n=44) \quad$ Panel B: Later Period ( $n=46)$

\begin{tabular}{|c|c|c|c|c|c|c|c|}
\hline Variable & Mean & Min & Max & Mean & Min & Max & $p$-Value \\
\hline VALUE_PROCEEDS* & 65.53 & 6.54 & 232.02 & 152.08 & 27.92 & 1306.23 & 0.016 \\
\hline VALUE_CLOSING* & 80.54 & 7.39 & 238.43 & 181.72 & 27.84 & 1176.39 & 0.008 \\
\hline NOBEL & 0.18 & 0 & 1 & 0.15 & 0 & 1 & 0.710 \\
\hline PERCENT_SOLD (\%) & 0.661 & 0.179 & 0.84 & 0.578 & 0.045 & 0.752 & 0.008 \\
\hline ALLIANCES & 3.59 & 0 & 32 & 8 & 0 & 35 & 0.001 \\
\hline EMPLOYEES & 58.84 & 5 & 172 & 88.46 & 8 & 276 & 0.015 \\
\hline MGR_SHARE (\%) & 0.031 & 0.001 & 0.183 & 0.041 & 0.001 & 0.236 & 0.736 \\
\hline PHASE & 1.14 & 0 & 8 & 1.89 & 0 & 7 & 0.047 \\
\hline PATENTS & 0.5 & 0 & 9 & 6.65 & 0 & 70 & 0.003 \\
\hline PATENT_CITES & 1.68 & 0 & 30 & 20.36 & 0 & 494 & 0.359 \\
\hline$R \& D \_E X P E N D^{*}$ & 11.87 & 0.4 & 47.16 & 20.41 & 2.05 & 97.48 & 0.001 \\
\hline VENTURE & 0.909 & 0 & 1 & 0.739 & 0 & 1 & 0.034 \\
\hline REVENUES ${ }^{*}$ & 5.09 & 0.001 & 42.83 & 9.69 & 0 & 118.81 & 0.087 \\
\hline BIO_RATIO & 0.110 & .058 & 0.117 & 0.121 & 0.033 & 0.167 & 0.160 \\
\hline TOTAL_CITES & 997 & 85 & 4,995 & 2,227 & 175 & 8,958 & 0.000 \\
\hline MAX_CITES & 352 & 34 & 1,307 & 673 & 81 & 1,921 & 0.000 \\
\hline $\begin{array}{l}\text { AGE (Months) } \\
\text { * Millions of current } \\
\text { Dollars }\end{array}$ & 51.7 & 3 & 124 & 70.9 & 14 & 193 & 0.013 \\
\hline
\end{tabular}




\section{Table 4: Econometric Results}

Panel A

NOBEL

NOBEL_AGE

PERCENT_SOLD

ALLIANCES

ALL_SQ

MGR_SHARE

$R \& D \_E X P E N D$

EMPLOYEES

PHASE

PATENTS

PATENT_CITES

VENTURE

BIO_RATIO

LATE

L_NOBEL

L_NOBEL_AGE

L_PERCENT_SOLD

L_ALLIANCES

L_ALLSQ

L_MGR_SHARE

L_R\&D_EXPEND

L_EMPLOYEES

L_PHASE

L_PATENTS

L_PATENT_CITES

L_VENTURE

L_BIO_RATIO

Observations

$R$-Square

*** Significant at $1 \%$

\begin{tabular}{c}
\hline VALU \\
\hline Coef. \\
\hline 0.9 \\
-0.0 \\
-2.0 \\
0.0 \\
-0.0 \\
0.0 \\
0 \\
0.1 \\
0.0 \\
-0.0 \\
0.0 \\
0.6 \\
3.0 \\
-4 \\
-1.0 \\
0.0 \\
1. \\
-0.0 \\
0.0 \\
-0.0 \\
-0. \\
-0.0 \\
-0.0 \\
0.0 \\
-0.0 \\
-0.4 \\
4.0 \\
0.8
\end{tabular}

\section{VAL}

ALUE_PROCEEDS VALUE_CLOSING

t-Stat

$\begin{array}{rr}0.939 & 3.26 \\ -0.053 & -2.01^{* * *}\end{array}$

$-2.049-6.64 * * *$

$0.051 \quad 1.67$

$-0.003-3.46^{* * *}$

0.0901 .92 *

$0.231 \quad 1.62$

$0.192 \quad 1.30$

$0.070 \quad 1.69$ *

$-0.061 \quad-0.95$

$0.011 \quad 0.69$

$0.641 \quad 1.52$

$3.048 \quad 0.85$

$-4.271-2.79$ ***

$-1.018-2.11^{\text {** }}$

0.0561 .90 *

$1.2223 .71^{* * *}$

$-0.077-1.81$ *

$0.0043 .15^{* * *}$

$-0.076-1.20$

$-0.218 \quad-1.24$

$-0.081 \quad-0.43$

$-0.009-0.15$

$0.078 \quad 1.20$

$-0.001 \quad-0.07$

$-0.474 \quad-0.98$

$4.038 \quad 0.93$

90

0.801

$$
\text { ** Significant at 5\% }
$$

$-0.009-0.17$

$0.001 \quad 0.54$

$\begin{array}{ll}-0.050 & -0.69\end{array}$

$-0.298 \quad-1.54$

$-0.012-0.05$

$-0.037-0.55$

$-0.030-0.50$

$\begin{array}{rr}-0.030 & -0.50 \\ 0.019 & 1.29\end{array}$

$-0.522-0.99$

$\begin{array}{rr}-0.522 & -0.99 \\ 4.821 & 0.96\end{array}$

\begin{tabular}{lll}
\multicolumn{3}{c}{ Panel B } \\
\begin{tabular}{lll}
\hline VALUE_PROCEEDS & VALUE_CLOSING \\
\hline Coef. t-Stat & Coef. & t-Stat
\end{tabular}
\end{tabular}

Coef.

Coef. t-Stat

$0.944 \quad 4.32$ ***

$-0.048-2.56$ **

$-1.889-7.21^{* * *}$

1.124

$-0.057$

$-2.006$

0.021

$-0.001$

0.069

0.358

0.190

0.085

0.014

$-0.004$

0.054

6.026

$-3.692$

$-1.411$

0.072

1.150

5.15 ***

$-2.67^{* * *}$

$-7.23^{* \star *}$

0.79

$-1.20$

2.12 **

3.22 ***

1.92 *

2.56 **

3.28 ***

$-0.92$

0.21

2.22 **

$-3.00 * * *$

-2.66 ***

2.39 **

3.90 ***

$90 \quad 90$

* Significant at 10\%
$-0.007$

0.001

0.792

$-0.17$

0.48

$\begin{array}{llll}-0.357 & -2.78^{* * *} & -0.395 & -2.69 * * *\end{array}$

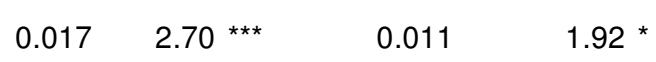

90

0.725 
Table 5: Alternative Models - VALUE_PROCEEDS

\begin{tabular}{|c|c|c|c|c|c|c|c|c|c|c|c|}
\hline & Panel A & & Panel B & & Panel C & & Panel D & & Panel E & & \\
\hline & Coef. & t-Stat & Coef. & t-Stat & Coef. & t-Stat & Coef. & t-Stat & Coef. & t-Stat & \\
\hline NOBEL & 0.948 & 4.15 *** & 1.006 & 4.60 *** & 0.875 & 3.42 *** & 0.909 & $3.69 * * *$ & 0.969 & 4.34 & $4 * * *$ \\
\hline NOBEL_AGE & -0.049 & $-2.46^{* *}$ & -0.056 & $-2.96^{* * *}$ & -0.047 & -2.22 ** & -0.050 & $-2.52^{* *}$ & -0.049 & -2.64 & $4^{* * *}$ \\
\hline PERCENT_SOLD & -1.886 & $-7.23^{* * *}$ & -1.871 & $-6.87^{* * *}$ & -1.916 & $-6.92 * * *$ & -1.920 & $-7.00 * * *$ & -1.867 & -6.94 & $4^{* * *}$ \\
\hline ALLIANCES & 0.040 & 1.66 & 0.043 & $1.67^{*}$ & 0.041 & 1.61 & 0.043 & 1.70 * & 0.046 & 1.77 & $7 *$ \\
\hline$A L L \_S Q$ & -0.003 & $-3.54^{\star \star \star}$ & -0.003 & $-3.47^{* \star *}$ & -0.003 & $-3.64^{* * *}$ & -0.003 & $-3.72^{* * *}$ & -0.003 & -3.42 & $2^{* * *}$ \\
\hline MGR_SHARE & 0.054 & 1.70 * & 0.059 & 1.99 * & 0.065 & $2.20 * *$ & 0.066 & $2.17^{\star *}$ & 0.054 & 1.76 & * \\
\hline$R \& D \_E X P E N D$ & 0.360 & $3.13^{* * *}$ & 0.387 & $3.89 * * *$ & 0.276 & $2.78^{* * *}$ & 0.298 & 2.92 *** & 0.354 & 3.63 & $3^{* * *}$ \\
\hline EMPLOYEES & 0.141 & 1.66 & 0.115 & 1.36 & 0.207 & $2.18^{* \star}$ & 0.192 & $2.09 * *$ & 0.147 & 1.82 & * \\
\hline PHASE & 0.070 & 2.32 ** & 0.073 & $2.71^{* * *}$ & 0.076 & $3.16^{* * *}$ & 0.073 & $2.70^{* * *}$ & 0.074 & 2.63 & $3 * *$ \\
\hline PATENTS & 0.017 & $4.35^{* \star *}$ & 0.021 & $5.05^{* \star *}$ & 0.019 & $5.65^{\star \star *}$ & 0.019 & $5.32^{* * *}$ & 0.016 & 3.85 & $5^{* * *}$ \\
\hline PATENT_CITES & -0.007 & -1.22 & -0.007 & -1.11 & -0.008 & -1.21 & -0.009 & -1.54 & -0.008 & -1.33 & \\
\hline VENTURE & 0.220 & 1.19 & 0.197 & 1.01 & 0.217 & 1.20 & 0.221 & 1.16 & 0.202 & 1.04 & \\
\hline BIO_RATIO & 6.042 & $2.89^{\star \star \star}$ & 6.695 & $3.46^{* \star *}$ & 5.904 & $3.40^{* * *}$ & 6.645 & $3.53^{* \star *}$ & 5.872 & 1.38 & \\
\hline LATE & -3.169 & $-2.64 * * *$ & -2.168 & -1.66 & -3.320 & $-2.56^{\star *}$ & -1.501 & -0.99 & -2.974 & -2.09 & ** \\
\hline L_NOBEL & -0.853 & -1.59 & -1.257 & $-3.01 * * *$ & -0.777 & $-1.75^{*}$ & -0.832 & $-1.88 *$ & -1.185 & -2.79 & $* * *$ \\
\hline$L \_N O B E L \_A G E$ & 0.045 & 1.65 & 0.067 & $2.89 * * *$ & 0.046 & 1.94 * & 0.050 & $2.12^{* *}$ & 0.056 & 2.49 & ** \\
\hline L_PERCENT_SOLD & 1.046 & $3.70^{* * *}$ & 1.029 & $3.61^{* * *}$ & 1.053 & $3.46^{* * *}$ & 1.087 & $3.68^{* * *}$ & 1.017 & 3.56 & *** \\
\hline L_ALLIANCES & -0.073 & $-1.99 *$ & -0.065 & $-1.86 *$ & -0.047 & -1.23 & -0.052 & -1.38 & -0.062 & -1.62 & \\
\hline L_ALLSQ & 0.003 & $3.21^{* * *}$ & 0.003 & $3.28^{* * *}$ & 0.003 & $2.82^{* * *}$ & 0.003 & $2.91^{* * *}$ & 0.003 & 2.99 & $* * *$ \\
\hline$L \_R \& D \_E X P E N D$ & -0.335 & $-2.08 * *$ & -0.412 & $-3.13^{* * *}$ & -0.313 & $-2.15^{* *}$ & -0.338 & $-2.48^{* *}$ & -0.368 & -2.79 & $* * *$ \\
\hline L_PATENTS_CITES & 0.017 & $2.50 * *$ & 0.021 & $2.62^{* \star}$ & 0.014 & 2.29 ** & 0.018 & $2.87^{* * *}$ & 0.017 & 2.43 & $3^{* *}$ \\
\hline RENENUES & -0.014 & -0.30 & & & & & & & & & \\
\hline L_REVENUES & 0.019 & 0.28 & & & & & & & & & \\
\hline$\overline{A G E}$ & & & -0.082 & -0.81 & & & & & & & \\
\hline L_AGE & & & -0.190 & -1.18 & & & & & & & \\
\hline TOTAL_CITES & & & & & 0.084 & 1.16 & & & & & \\
\hline L_TOTAL_CITES & & & & & -0.336 & $-2.68^{* * *}$ & & & & & \\
\hline MAX_CITES & & & & & & & 0.048 & 0.48 & & & \\
\hline L_MAX_CITES & & & & & & & -0.316 & -2.14 ** & & & \\
\hline CUM_BIOTECH & & & & & & & & & 0.004 & 0.68 & \\
\hline L_CUM_BIOTECH & & & & & & & & & -0.003 & -0.24 & \\
\hline Observations & 86 & & 90 & & 90 & & 90 & & 90 & & \\
\hline$R$-Square & 0.806 & & 0.804 & & 0.821 & & 0.811 & & 0.794 & & \\
\hline *** Significant at $1 \%$ & & ${ }^{* *}$ Significar & $5 \%$ & ${ }^{*}$ Significal & $10 \%$ & & & & & & \\
\hline
\end{tabular}




\section{Table 6: Compensation of Nobel Laureates}

\section{Panel A: 1989 to 1992 IPO window}

Firm

Max Nobel Compensation

Alteon
CellPro
Cephalon
Gilead Sciences
Magainin Pharmaceuticals
Regeneron Pharmaceuticals
Somatogen
Systemix

$\$ 8.87$ million

$\$ 4.54$ million

$\$ 6.81$ million

$\$ 11.35$ million

$\$ 4.02$ million

$\$ 15.13$ million

$\$ 7.49$ million

$\$ 11.63$ million

\section{Panel B: 1996 to 2000 IPO window}

Firm

Antigenics

Aviron

Cell Therapeutics

CV Therapeutics

Geron

Maxygen

Orchid Biosciences
Max Nobel Compensation

\$3.1 million

$\$ 3.97$ million

$\$ 4.25$ million

$\$ 2.51$ million

$\$ 3.2$ million

$\$ 17.5$ million

\$10.84 million 